\title{
Physical education in Primary Health Care: reports on interactive actions in an undergraduate course
}

\section{Educação física na atenção primária à saúde: relatos de ações interativas em disciplina de graduação}

\section{AUTHOR'S \\ Danilo Fernandes da Silva ${ }^{1}$ (D) \\ Silvano da Silva Coutinho ${ }^{2}$ (ID) \\ Helena Piccinini-Vallis ${ }^{3}$ (D) \\ Marcos Roberto Queiroga ${ }^{1}$ (D) \\ 1 Midwestern Parana State University, Department of Physical Education, Guarapuava, Parana, Brazil. \\ 2 Midwestern Parana State University, Department of Physical Education, Irati, Parana, Brazil. \\ 3 Dalhousie University, Department of Family \\ Medicine, Halifax, Nova Scotia, Canada.}

\section{CORRESPONDING}

Marcos Roberto Queiroga

queirogamr@hotmail.com

Rua Simeão Varela de Sá, 03 - Vila Carli,

Guarapuava, Paraná, Brasil.

CEP: 85040-080.

DOI

$10.12820 /$ rbafs. $23 \mathrm{e} 0048$

\section{(cc) BY-NC-SA}

This work is licensed under the Creative Commons Attribution-NonCommercial-ShareAlike 4.0 International License.

\begin{abstract}
The objective this study was to describe experiences that reflect interactive actions in the program content of the Physical Education and Primary Health Care (PHC) course in the undergraduate (bachelor) degree in Physical Education at the Midwestern Parana State University (UNICENTRO). Activities that aimed to promote students' understanding of the area and of their role in the health care team through interactions with other professors and professionals from the multidisciplinary residency with emphasis in family health for professionals of Physical Education, Nutrition, Nursing and Physical Therapy are described. The highlighted activities include a review of the legislation supporting the inclusion of the Physical Education professional in the PHC as well as documentaries based on previous reports from a professor in the area. Moreover, studies regarding the skills of the Physical Education professional in Primary Health Care, a comparison between the reality of Primary Health Care in Canada and the PHC, and the interventions developed by the multidisciplinary residents representing Physical Education. We hope this experience report facilitates continuous discussion about the teaching-learning process in the field of Physical Education and public/collective health, mainly in the field of Primary Health Care.
\end{abstract}

Keywords: Primary health care; Exercise; Public health; Health centers.

RESUMO

O objetivo desse estudo foi relatar experiências que refletem açôes interativas no conteúdo programático da disciplina "Educação física na atenção primária à saúde" do curso de bacharelado em Educação Física da Universidade Estadual do Centro-Oeste (UNICENTRO). São descritas atividades que conduziram acadêmicos a aprofundar-se na área e perceber seu papel na equipe de saúde através de interaçôes com outros docentes e alunos da residência multiprofissional com ênfase em saúde da família para profissionais de Educação Física, Nutrição, Enfermagem e Fisioterapia. Entre as atividades estão o entendimento da legislação respaldando a inserção da Educação Física no Sistema Único de Saúde (SUS), os documentários baseados em relato de experiência de professor da área, os estudos das competências do profissional de Educação Física na atenção primária à saúde, as comparaçôes com a realidade da atenção primária à saúde no Canadá e as intervençôes desenvolvidas pelos residentes de Educação Física na residência multiprofissional. Espera-se que esse relato propicie discussão continuada sobre o processo ensino-aprendizagem na área de Educação Física e saúde públicalcoletiva, sobretudo na atenção primária à saúde.

Palavras-chave: Atenção primária à saúde; Exercício; Saúde pública; Centros de saúde.

\section{Introduction}

With the reform and implementation of the new academic curriculum for the Bachelor's in Physical Education (PE) at the Midwestern Parana State University (UNICENTRO, Guarapuava, Paraná) in 2015, a course titled "PE in Primary Health Care" was created with the first class to be initiated in 2017. Also during this period with known participation from the PE department at the institution, the Program in Multiprofessional Residency in Primary Health Care with an emphasis in family health, approved in 2015, was implemented in
2016 and, since, has annually offered two job opportunities for PE, Nutrition, Physical Therapy, and Nursing graduates. Therefore, it was identified that a course that could contribute to qualify and promote the interest in students to Primary Health Care (PHC) was needed. Through literature ${ }^{1}$ and exchanges with specialists in the field, researchers, faculty, tutors, health teams, and residents, especially those in $\mathrm{PE}$, the course "PE in Primary Health Care" was planned, also counting on interactive actions, to lead the undergraduate to deepen their knowledge in the field and identify their role in 
the health team.

These interactive actions represent the direct or indirect activities with contribution of faculty and $\mathrm{PE}$ professionals as well as others in health-related fields with experience in Primary Health Care and were tools for the enrichment of discussion on the topic with students. Experiences reported helped responding some of the objectives of the course. We hope this report adds value to the academic discussions on the training of $\mathrm{PE}$ professionals in the context of Primary Health Care. Therefore, the aim of this article is to report experiences that reflect the interactive actions in the academic curriculum of the course in PE in Primary Health Care in a bachelor's degree in PE at UNICENTRO.

\section{Presenting the course}

The first class in the bachelor in PE with the current academic curriculum initiated in 2015, and the course was offered in 2017 (junior year). This course is offered annually with a weekly load of 102 class/hours, where the syllabus focuses on the insertion and practice of $\mathrm{PE}$ professionals in the context of Primary Health Care, aiming to identify, discuss, and build possibilities of interventions from problems and needs in health that will be brought from the environment of Primary Health Care Units. The objectives are detailed on Table 1.

Table 1 - Learning objectives for the course "Physical Education and Primary Health Care" at UNICENTRO.

\begin{tabular}{|c|c|}
\hline Order & Learning objectives \\
\hline 1 & $\begin{array}{l}\text { Present the regulation and public policies that guide the insertion } \\
\text { of the PE professional in health, especially in the context of } \\
\text { primary care. }\end{array}$ \\
\hline 2 & $\begin{array}{l}\text { Analyze theoretical and practical concepts for "health promotion" } \\
\text { and "disease prevention". }\end{array}$ \\
\hline 3 & $\begin{array}{l}\text { Discuss the organization and practice model for the Primary Care } \\
\text { Units (PCU) and establish a parallel with the reality in other } \\
\text { countries. }\end{array}$ \\
\hline 4 & $\begin{array}{l}\text { Analyze the Nuclei of Support to Family Health, practice } \\
\text { in multiprofessional teams and the competencies of Physical } \\
\text { Education professionals. }\end{array}$ \\
\hline 5 & $\begin{array}{l}\text { Debate the training and practice of the Physical Education } \\
\text { professional in undergraduate and multiprofessional residency } \\
\text { programs in health. }\end{array}$ \\
\hline 6 & $\begin{array}{l}\text { Understand the main demands of the Physical Education } \\
\text { professional in public health. }\end{array}$ \\
\hline 7 & $\begin{array}{l}\text { Present possible tools/interventions to address the demands of the } \\
\text { Physical Education professional. }\end{array}$ \\
\hline 8 & $\begin{array}{l}\text { Assist in bridging the gap between scientific knowledge and } \\
\text { professional practice in the context of public health. }\end{array}$ \\
\hline
\end{tabular}

Note: Objectives 1, 3, 4, 5, 6 are addressed in the reported experiences. Objectives 2, 7 and 8 include other experiences that were not reported in this article.
It is noticeable that some of the objectives are broad and common to any health professional, however, with the advance of these discussions, deeper conversations were carried out on the specificity of the PE professional. Prior to the start of the content, students' knowledge on the Unified Health System (UHS, SUS in Portuguese) was reviewed and became the anchor to the sequence of the course ${ }^{2}$. This was made possible by a semi structured survey developed by the Program in Tutorial Education (PTE) in PE at the State University of Maringa ${ }^{3}$, including questions such as: "Have you ever used the SUS?", "How would you evaluate PHC' services?", "Prior to starting your undergraduate degree, did you know about the possibility of working in Primary Health Care?".

\section{Description of educational experiences}

Experience 1-Legislation supporting the insertion of the PE professional in the context of the PHC The idea for this activity was to promote the interaction, in a logical way, between legal documents that support the insertion of the $\mathrm{PE}$ professional in the context of the PHC. The start of this discussion was given from the federal constitution of 1988 and the organic laws \#8080/90 and \#8142/905 which constitute the legal basis of the PHC. The students understood that the creation of the system is a result of political actions sustained by democratization movements in Brazil. Therefore, the creation of the PHC aimed to strengthen the political decentralization process and open spaces for popular participation.

It was also discussed the implementation of the Program Family Health in 1994 by the Ministry of Health. Students were able to analyze their role in the restructuring of Primary Health Care and the professionals who initially were a part of it. Resolutions \#218/1997 and \#287/1998 ${ }^{7}$ of the National Health Council were presented and highlights the importance of multiprofessional actions, as well as recognized the health professionals, among them the PE professionals.

Students were also introduced to law \#9696/1998 which regulates the professional in $\mathrm{PE}$ as a legally organized and integrated to the health and education fields ${ }^{8}$. Also, the documentation promoting national curricular standards for bachelor degrees in $\mathrm{PE}$, \#0138/02, 2002, from the CNE/CES, as seen in a study by Tojal ${ }^{9}$. 
Finally, a debate on the publication \#687/2006 from the Ministry of Health, which described the National Policy for Health Promotion (PNPS). It was emphasized that among specific actions mentioned in the document there is the promotion of bodily practices and physical activities ${ }^{10}$, through mapping and support to existing actions in primary care services and in the Strategy for Family Health and offering of activities such as walks, prescription of exercise, recreation, sports, and leisure practices. Summed to this, the bill \#154/2008 from the Ministry of Health ${ }^{11}$, which created the Nuclei for Support of Family Health, being the basis of the National Policy for Health Promotion (PNPS). The text refers to the participation of PE professionals in support of the Family Health program and consider law \#9696/1998 which regulates the PE profession ${ }^{8}$. Other documents following this insertion or updating previous documents were also discussed with students, however, this activity had the goal to know and create with students a timeline for the insertion of the $\mathrm{PE}$ professional in the context of Primary Health Care.

\section{Experience 2-Activities based in experiences by} Professor Loch

Through this activity, we aimed to interact with the experiences reported by Loch', faculty in Physical Education and Public Health in the Physical Education major at State University of Londrina, as well as demonstrate how knowledge obtained in documentaries could be debated with scientific knowledge and how that relationship with science is important when critically analyzing documentaries. Among the activities based in Loch's teaching experiences, there are three documentaries: "SOS Health" (2006) by Michael Moore, USA; "O renascimento do parto" (The rebirth of childbirth, in English) (2013) by Erica de Paula and Eduardo Chauvet, Brazil and "Muito além do peso" (Beyond the weight, in English) (2012) by Estela Renner, Brazil. Other relevant questions were brought up with students, such as:

1) The relationship between the documentary SOS Health and the implementation of Obamacare and its discussions in the USA, for example: the article published by the former president of the United States in NEJM $^{12}$ and the critical analyses on Obamacare ${ }^{13}$;

2) A deeper discussion on part 6 of the documentary "Rebirth of childbirth", narrating medical practices that are based in dogmas in some contexts, for example, obstetric practices with low level of interaction between scientific evidence and a possible parallel with $\mathrm{PE}^{14}$;

3) The association of the documentary "Beyond the weight" with most recent prevalence data, etiology, and consequences of obesity in the population in general but, moreover, in children and adolescents, debating how to revert the crescent prevalence of child-adolescent obesity ${ }^{15}$.

\section{Experience 3 - Experience with Professor Coutinho}

As faculty at Unicentro in the bachelor in PE, Irati, Paraná Campus, Professor Coutinho defended his doctoral dissertation in 2011 at the University of São Paulo ${ }^{16}$, entitled "The competencies of the PE professional in Primary Health Care". His aims were to elaborate and analyze the competencies required by the $\mathrm{PE}$ professional to be able to work in Primary Health Care based on professionals working in programs to promote bodily practices/physical activities at primary care within the PHC and researchers studying the theme $\mathrm{PE}$ and $\mathrm{PHC}$.

Summarizing, his work analyzed three dimensions of competencies and its subdivisions as can be seen in Figure $1^{17,18}$.

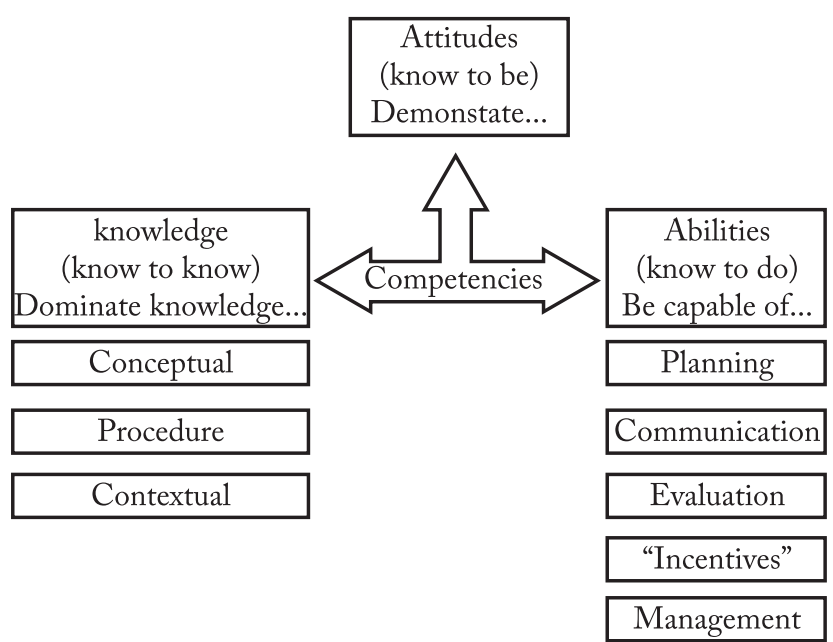

Figure 1 - Dimensions and subdivisions of professional competencies. Adapted from: Durand ${ }^{17}$; Feitosa $\&$ Nascimento ${ }^{18}$.

These guidelines were presented to students, added to the application of the "Instrument for self-evaluation of professional competencies in PE in Primary Health Care", aiming to determine the perception of $\mathrm{PE}$ professionals on their level of mastery in professional competencies demanded in that context. Even 
knowing the questionnaire is not aimed at students but professionals working in primary care, this experience was enriching as it served as a teaching process on what is a demand in primary care and to what degree they are competent to practice. The instrument was also a guideline for future practice of students in Primary Care. In this sense, we understand students may use the competencies as glimpse of diversity and complexity that this work involves, since these are constructed from professional practice ${ }^{16}$. It was also possible for students to identify terms specific to public health and not normally used in traditional courses in a bachelor in $\mathrm{PE}$ and this allowed for broadening of the discussion and knowledge on the theme.

\section{Experience 4-Experience with Professor Helena Piccinini-Vallis}

Professor Helena Piccinini-Vallis is a Family physician (or medical doctor) in the city of Halifax, Nova Escotia, Canada. Her experience is in public health, especially in the context of primary care. Professor Piccinini-Vallis contributed through video summarizing this practice field.

The country she is in has its own public health system known as Medicare. There are five universal conditions for its application: 1) Administration by a public authority and not for profit; 2) Medically necessary services must be ensured; 3) All residents of Canada must have access to insured public health services; 4) Those living in the country must have access to portability (i.e., access in any Canadian province or territory and, somewhat, also abroad); 5) Accessibility of those insured homogeneously, with no financial or other barriers.

An important question during her talk was the affirmation that services for primary care in Canada are based in the model of disease that is centered in the physician. Another relevant point is the entry of the user in the public health system that is always given through a consultation/assessment made by a family doctor. According to her, this is the point where most difficulties are found since physicians are trained to practice focused on a biomedical model (i.e., biophysiological explanations), without the full understanding of the psychosocial model and no governmental support to practice this model.

As an example, she reports practicing with obese patients. The normal practice model restricts the time spent with patients, not allowing for a deep understanding of the case, life context, aspects connected to the development of the disease, which prevents effective conduct with the patients. She points out that it would be beneficial to be able to forward this patient to a multiprofessional environment, which would include PE professionals among others. However, since the health system does not over these services, the patients would need to take on the costs or have some sort of insurance.

Therefore, she valued the organization from the documental/conceptual point of view for the Brazilian public health system, mostly on the opportunities offered in primary care and the interaction and work in multiprofessional teams.

Experience 5-Experience with multiprofessional residence

Looking to amplify the interaction with multiprofessional residency, four PE residents (R1 and R2) were invited to narrate their experiences in the final part of the course. Students now more experienced on the possibilities of practice as $\mathrm{PE}$ professional in primary care, analyzed the content presented by residents looking to classify the activities within three types of actions described by Silva ${ }^{19}:$ 1) Group activities; 2) Individual/ Home Activities; 3) Actions for health education.

Additionally, they were able to notice from narratives the real experiences of the disciplines composing the multiprofessional interactions in this institution and the possibility for joint actions developed by residents with other sectors in the community such as churches, schools, city halls, etc. (i.e., intersectorial actions). Residents presented to students examples of case studies within individual treatments that were considered more complex and reported how this complexity in the interaction between multiple diseases and treatments (e.g., non-medication vs. medication) for a single patient that complicate action of $\mathrm{PE}$ professionals in the elaboration of intervention programs.

Students were encouraged to conduct searches in scientific literature that focused on recommendations for physical exercise for different special populations presented by the residents and an exercise to contrast those guidelines recommendations with difficulties found in real-life experiences. Among those difficulties, the debate suggested there are strong economic, political, and cultural impacts among the barriers for $\mathrm{PE}$ professionals to practice. It is worth to highlighting that the contact with residents also allowed students to understand the opportunity for continuing education 
after graduation.

\section{Final considerations}

Through the experiences and interactions with professor who contributed to the course, it was possible to enrich the contents and give students a depth through the ways that lead to the insertion of $\mathrm{PE}$ professionals in Primary Health Care, from legal aspects to conceptual, comparison with other realities, professional education and competences for practice, looking for connections between theory and practice in the construction of activities.

Among the benefits of the course we may include some examples of activities developed analytically and evaluatively with students by faculty: 1) the construction of a chart in the form of a timeline summarizing legal documents; 2) the dissertation of a text critically analyzing documentaries interacting with scientific articles on the relevant themes; 3 ) a dissertation text analyzing the narrative of residents and its agreement with theoretical references ${ }^{19}$, as well as the competencies by $\mathrm{PE}$ professionals in primary care; 4) Seminars and exams to contextualize the contents provided by the experiences.

When students face the courses in a PE major, many times they do not realize how practice in primary care, especially in the context of the $\mathrm{PHC}$, requires interdisciplinary discussion involving factors that are social, cultural, biological, technical (e.g., tools for evaluation and prescription), sports, and leisure. The interactions and multiplicity of experiences offered by the current course contributed to the minimization of this gap in education, mostly when considering the complementary role of other faculty. Even so, we judge the interactions that are deeper with other majors in the health field on practice in Primary Health Care could make this course even more positive for qualification of students, that being the goal for the course in the upcoming years.

Reporting the options used for offering this course, we have the intention to share the diversity of pedagogic options that were used looking to amplify the experience of students. If on one hand Primary Health Care is still an emergent field for $\mathrm{PE}$, on the other hand, it is also characterized as a space where many new experiences are being developed and tacit and explicit have been built. We believe that this potential must be incorporated to academic training as a way to approximate the university to the context of health service.

\section{Conflicts of interest}

The authors declare there are no conflicts of interest.

\section{Author contributions}

Silva DF, participated in the initial conceptualization of the study, taught the interactive experiences cited in this article, contributed substantially to writing, critical review, and approval of final version of the manuscript. Coutinho SS, participated in the interactive experiences cited in this article, contributed substantially to writing, critical review, and approval of final version of the manuscript. Piccinini-Vallis H, participated in the interactive experiences cited in this article, contributed substantially to writing, critical review, and approval of final version of the manuscript. Queiroga MR, participated in the initial conceptualization of the study and implementation of the course, contributed substantially to writing, critical review, and approval of final version of the manuscript.

\section{Acknowledgements}

To the residents who reported their experiences during the Multiprofessional residence in Family Health at Unicentro.

\section{References}

1. Loch M. Abordando Saúde Coletiva no curso de bacharelado em Educação Física: Relato de experiência. Rev Bras Ativ Fis Saúde. 2016;21(3):285-90.

2. Masini EFS, Moreira MA. Aprendizagem significativa: A teoria de David Ausubel. São Paulo: Centauro, 2006.

3. Silva DF, Bevilaqua CA, Belém IC, Delfino RD, Yusunaka K, Nardo Junior, N. Percepção de acadêmicos de educação física quanto ao sistema único de saúde (SUS). Anais do CISDEM, Maringá, Paraná, 2009.

4. Brasil. Lei no 8.080, de 19 de setembro de 1990. Lei Orgânica da Saúde. Dispõe sobre as condições para a promoção, proteção e recuperação da saúde, a organização e o funcionamento dos serviços correspondentes e dá outras providências. Brasília: DF. 1990.

5. Brasil. Lei no 8142, de 28 de dezembro de 1990. Lei Orgânica da Saúde. Dispõe sobre a participação da comunidade na gestão do Sistema Único de Saúde (SUS) e sobre as transferências intergovernamentais de recursos financeiros na área da saúde e dá outras providências. Brasília: DF. 1990.

6. Brasil. Conselho Nacional de Saúde. Resolução no 218, de 06 de março de 1997. Reconhecimento de categorias profissionais como profissionais da saúde. Brasília: DF. 1997.

7. Brasil. Conselho Nacional de Saúde. Resolução no 287, de 08 de outubro de 1998. Relação de categorias profissionais de saúde de nível superior para fins de atuação do Conselho. Brasília: DF. 1998.

8. CONFEF. Legislação citada anexada pela coordenação de estudos legislativos - CEDI, Lei No 9696 de 1 de setembro de 1998.

9. Tojal JB. Diretrizes curriculares para o bacharelado em Educação Física: novos rumos. Rev Educ Fís UEM. 2003;14(2):105-12.

10. Brasil. Política Nacional de Promoção da Saúde ministério da saúde Secretaria de Vigilância em Saúde Secretaria de Atenção à Saúde. Brasília, Governo Federal: Ministério da Saúde, 2006. 
11. Brasil. Portaria no 154 de 24 de janeiro de 2008. Cria os Núcleos de Apoio a Saúde da Família - NASF. Brasília, Governo Federal: Ministério da Saúde, 2008.

12. Obama BH. Repealing the ACA without a replacement: the risk to American Health Care. $N$ Engl J Med. 2017;376(4):297-9.

13. Manchikanti L, Helm II S, Benyamin RM, Hirsch JA. A critical analysis of Obamacare: Affordable care or insurance for many and coverage for few? 2017;20:111-38.

14. CONFEF. Recomendações sobre condutas e procedimentos do professional de Educação Física na Atenção Básica à Saúde. 5a Ed. Rio de Janeiro: CONFEF, 2017.

15. WHO. Report of the Commission on Ending Chidlhood Obesity.WHO Library Cataloguing-in-Publication Data, 2016.

16. Coutinho SS. Competências do profissional de Educação Física na Atenção Básica à Saúde [tese de doutorado]. Ribeirão Preto: Escola de enfermagem de Ribeirão Preto, Universidade de São Paulo; 2011.
17. Durand T. L'alchimie de la compétence. Rev Fran Gest. 2000;127:84-102.

18. Feitosa WMN, Nascimento JV. As competências específicas do profissional de Educação Física que atua na orientação de atividades físicas: um estudo Delphi. Rev Bras Ciênc Movimento. 2003;11(4):19-26.

19. Silva PSC. Núcleo de Apoio à Saúde da Família. Aspectos legais, conceitos e possibilidades para a atuação dos Profissionais de Educação Física. 1ª Ed. Florianópolis: Editora Unisul, 2016.

\section{Quote this article as:}

Silva DF, Coutinho SS, Piccinini-Vallis H, Queiroga MR. Physical education in Primary Health Care: reports on interactive actions in an undergraduate course. Rev Bras Ativ Fís Saúde. 2018;23:e0048. DOI: 10.12820/rbafs.23e0048 